\title{
ANALYSIS OF THE LABOUR MARKET IN THE REPUBLIC OF MACEDONIA ACCORDING TO THE LEVEL OF EDUCATION
}

\author{
KOSTADINKA CABULEVA', EMILIJA MITEVA-KACARSKI", MARINA RADOSAVLAJEVIK-BOJCEVAIII \\ Univerzity Goce Delcev, Stip, Macedonia
}

\section{ABSTRACT}

The current educational system has to prepare the students for professions which should develop tomorrow. The key role of education at this moment in time ought to be the ability to predict the changes and to adapt to them successfully. The final resultant of the educational process is the acquisition of skills which will enable the pupils or students to adapt to the labour market quickly and easily. The connection of education with the labour market is the principal aim of the economy being based on knowledge.

In this paper, we make an effort to create an analytic framework for the representation of the educational profiles at the labour market in the Republic of Macedonia. The data contained in the analysis points out to the fact that out of the total number of employees according to their education in the period of 2001-2012, the biggest per cent of employees belongs to the ones with secondary education (three-year and four-year secondary education). In 2001, this percentile participation was $49.6 \%$ whereas in 2012 , this per cent increased to $53.6 \%$. The second position is being taken up by the employees with primary and lower secondary education (25.42\% in 2001). However, as a result of the fact the employment rate had been reducing year by year, in 2012 , it was $18.53 \%$. The employees with university education are taking up the third position. In 2001, the percentile participation of employees with university education was $10.53 \%$ whereas in 2012 , it was $21.6 \%$. This trend is due to the dispersed studies in a large number of towns in the Republic of Macedonia, which have led to increase in the number of graduates. Having in mind this analysis, the public educational institutions are facing the challenge to alter their current structure, to bring about a new structural change and to develop an organizational structure which will be compatible with the general changes at the labour market.

\section{JEL CLASSIFICATION \& KEYWORDS}

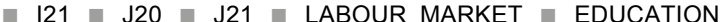 - EMPLOYMENT = UNEMPLOYMENT \\ INTRODUCTION}

Education is often used as a measure of the human capital and the level of skills of an individual. This indicator shows how well the skills supply is proportioned with its demand. For instance, the high rates of unemployment could point out to the disproportion between the education levels of the population and the demands of the labour market.

There is justification in the belief that the level of education is one of the key determinants of the state of the labour market. For example, the people with secondary education are more often unemployed in comparison with those with university education, but this conclusion cannot be

\footnotetext{
' kostadinka.cabuleva@ugd.edu.mk

" emilija.miteva@ugd.edu.mk

III marina.radosavljevik@ugd.edu

www.journals.cz
}

generalized because it should be taken into account the educational structure of the population. As a result of that, a range of scientists devote considerable attention to the understanding of the relationship between the level of education and the labour market. The key finding of the research is that this ratio has changed considerably during the last decades. Namely, there has been documented a trend of salary increase in accordance with the educational achievements i.e. the higher the level of education, the bigger the opportunity for earnings. For example, every single dollar spent on education at an individual level, results in 10 to 15 dollars input in the form of higher incomes and salaries during the individual's life. (OECD, 2013). The improvement of literacy is an important way of increasing the labour productivity, increasing GDP per capita and of reducing poverty. The countries having an opportunity to reach literacy, bigger than 1 percent point of the international average, will achieve $2.5 \%$ higher productivity of labour and $1.5 \%$ growth of GDP rather than the countries with average literacy. Totally, 171 million people could save themselves from poverty if all the students of poor countries would learn to read. (PerlmanRobinson, 2011).

The Republic of Macedonia is taking measures which guarantee equal opportunities for education of every citizen, irrespective of their age, sex, nationality or religious affiliation. The Government of the Republic of Macedonia and the Ministry of Education and Science are responsible for the provision of equal conditions for access to all kinds of education of every citizen.

The developmental orientation of the Republic of Macedonia is being focused on involving the country in the global processes of integration at a European and world level. The purpose of the country of entering the EU shall open a broad spectrum of possibilities for cooperation. The quality and intensity of cooperation will first of all depend on the readiness and ability of the country to follow the standards of quality and the essential criteria for achieving such cooperation, and the education has a key role in achieving such competence and competitiveness at the European and world markets.

\section{Trends of labour market by level of education}

Education has to be in correlation with the variable needs of the labour market. The connection of education with the labour market will improve itself by intensifying the cooperation with business and industry. The role of the educational system does not cease that moment when its participants abandon the educational institutions, but the modern concept of the educational system must be based on the principles of flexibility, functionality and openness. The dynamics of the changes in the educational system has to be conditioned by the dynamics of the changes in the necessary competences dictated at the labour market. In this context, the current needs of the economy cannot be fulfilled by an isolated educational 
system. The causative - consecutive relationship between the education and the labour market is apparently clear. Namely, the data about the employment and unemployment rates represents a basis for estimation of the long-term labour-market trends and variations between men and women with different level of education and of different age (World Bank \& ETF, 2008). This data can help the Governments understand better how their economies will develop in the upcoming years. On the other hand, the interpretation and taking into account of this data would be a starting basis for reforming the education policies in a direction for better preparation of the future participants at the labour market. In addition to this, there are presented quantitative analyses of the labour market of the Republic of Macedonia according to different criteria.

\section{Employees by level of education}

The percentile variation of employees by the level of education in the time-span of 2001-2012 is presented in the following chart:

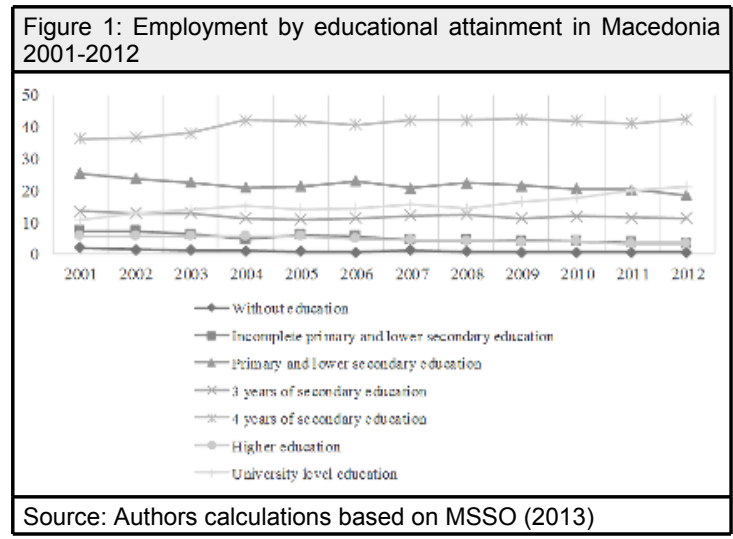

It can be seen from the data presented in Figure 1 that out of the total number of employees according to their education in the period of 2001-2012, the biggest per cent of employees belongs to the ones with secondary education (three-year and four-year secondary education). In 2001, this percentile participation was $49.6 \%$ whereas in 2012 , this per cent increased to $53.6 \%$. The second position is being taken up by the employees with primary and lower secondary education (25.42\% in 2001). However, as a result of the fact the employment rate had been reducing year by year, in 2012 , it was $18.53 \%$. The employees with university education are taking up the third position. Starting from 2001 up to 2008 , there can be seen variations in the percentile participation, but from 2008 up to 2012 the rate was in constant growth. In 2001, the percentile participation of employees with university education was $10.53 \%$ whereas in 2012 , it was $21.6 \%$.

\section{The unemployed by level of education}

The percentile variation of the unemployed by the level of education in the time-span of 2001-2012 is presented in the following chart.

In the period of 2001-2012, the unemployment rate in all school preparations in relation to the total number of the unemployed by education had been marking down minimal changes year by year, in a direction of growth and/or reduction.

It can be seen in Figure 2 that starting from 2001 up to 2008 , the highest unemployment rate refers to individuals with

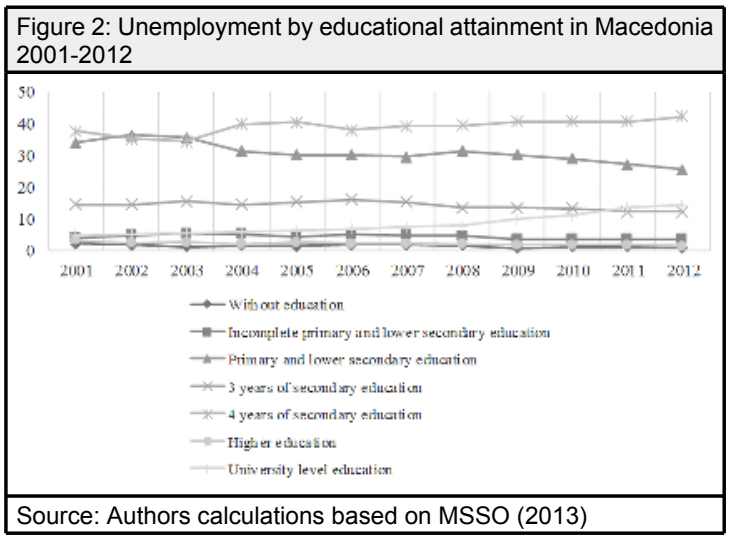

secondary education (three-year and four-year secondary education), being followed by those with primary education. The unemployment of individuals with three-year and four-year secondary education increased from $52.14 \%$ in 2001 to $54.5 \%$ in 2012 whereas the one of individuals with primary education decreased from $25.42 \%$ to $18.53 \%$. The unemployment rate of individuals with university education marked down constant growth from $4.78 \%$ in 2001 to $12.23 \%$ in 2012 .

One of the assumptions about increasing the unemployment rate of individuals with university and secondary education (in the last several years) is the fact that there have been made huge changes in the education, i.e. the institution of compulsory secondary education and the dispersal of university education (Yemtsov et al., 2006). In 2007/2008, it was enacted a law for compulsory secondary education, and as a result, it was increased the number of individuals who completed secondary education. As from 2008, the university education started being accessible to a large part of the population i.e. there were initiated dispersed studies in a large number of towns in the Republic of Macedonia, which have led to increase in the number of graduates. (World Bank, 2008)

In line with Commander and Kollo's (2004) observation that unemployment in all transition economies affects disproportionately the unskilled, low-educated workers, the probability of unemployment incidence in the Republic of Macedonia declines with the educational level.

"For example in 2008, unemployment rate with university level education was $7.76 \%$, with upper secondary education (excluding 3 years of secondary education) $39.37 \%$, and with lower than upper secondary (including 3 years of secondary education), $50.87 \%$."

If it is made a comparison between the level of education of the labour force and the unemployment, it can be noted a significant disproportion between the supply and the demand for qualification of the labour force in the Republic of Macedonia. The share of the less educated workers in the total labour supply is much higher than their share in the labour demand so that there is excess supply of these workers. "Hence, workers with only primary education or less have very high unemployment rates (for 2008 year $-31.46 \%$ ) and the lowest employment rates (22.35\%)."

\section{Employees by level of education and gender}

The percentile variation of employees by the level of education and gender in the time-span of 2001-2012 is presented in the following charts: 

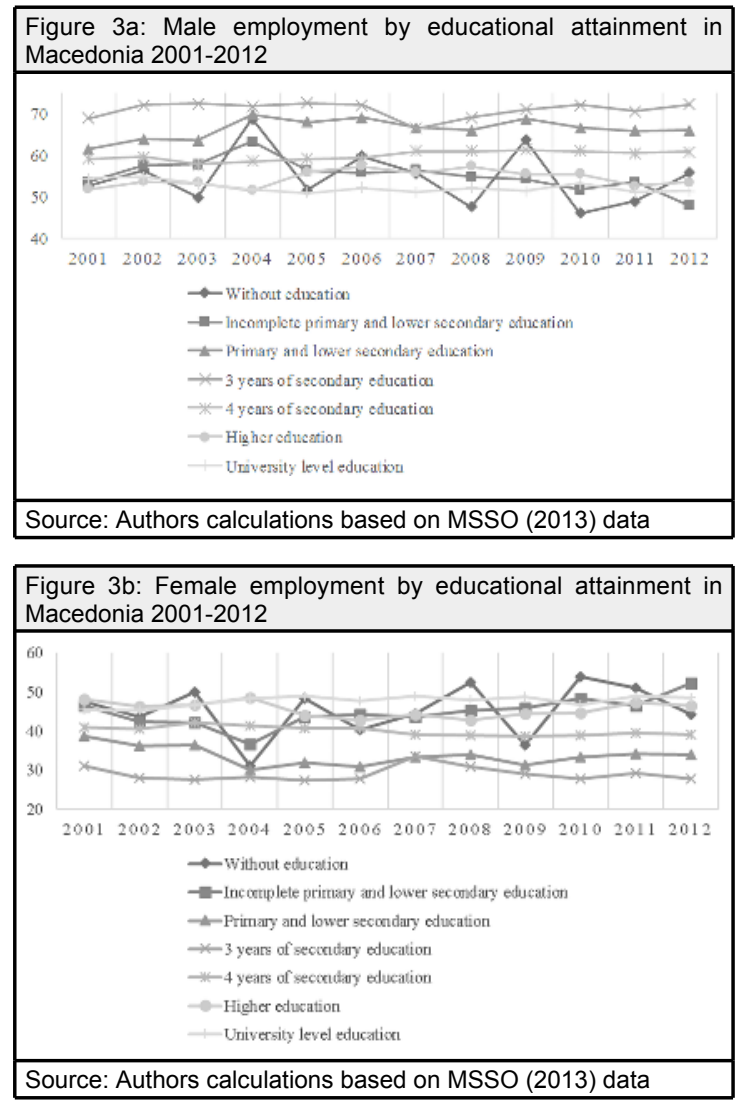

The combined analysis of employment by education and gender suggests that the employment rate of the male population at the lower levels of education is higher than that one of the female population. If we make an analysis of the entire time series (2001-2012), it can be seen that it dominates the employment of men with low secondary school preparation (3 years of secondary education). This data refers in average to about $70 \%$ of the men in the analyzed period. Among the women, there are obvious variations in the representation of educational profiles through the process of employment in the analyzed period. In 2012, 52.1\% of the employed women i.e. more than half are with incomplete primary and lower secondary education. This situation can be explained by the fact that the types of work being offered to individuals with lower level of education (greater physical fitness) are typical for men in the agriculture, industry and civil engineering which as sectors accumulate large part of the labour force in the Republic of Macedonia. However, in some sectors where no high level of education is needed, for instance the textile industry as one of the leading processing industries in the country having considerable results in the creation of GDP, the high absorption of labour force and the export, nearly all of the employed are women.

\section{The unemployed by level of education and gender}

The percentile variation of the unemployed by level of education and gender in the time-span of 2001-2012 is presented in the following charts.

Figures $4 \mathrm{a}$ and $4 \mathrm{~b}$ shows that the rate of unemployment by level of education and gender at the lower levels of education is higher in the male population rather than
Figure 4a: Male unemployment by educational attainment in Macedonia 2001-2012
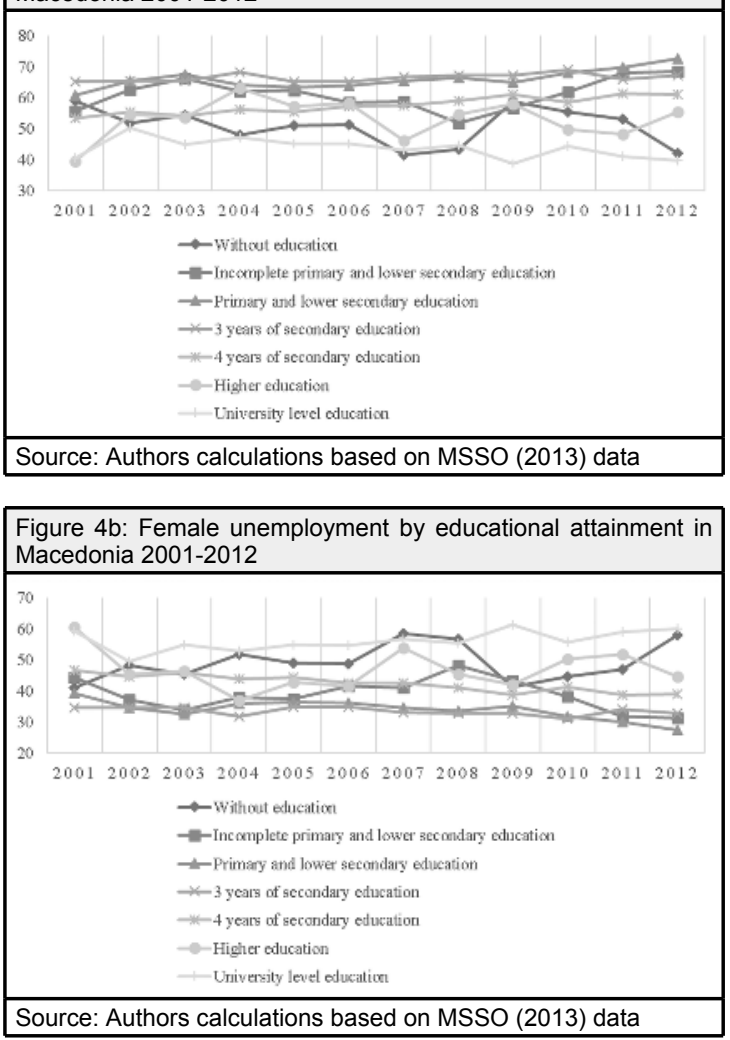

in the female one, whereas at the higher levels of education, the situation is reverse. Namely, the share of women in the labour force is small, especially of those women who have only primary education or less. The possibility for women with low level of education to take part in the labour market is even smaller. Therefore, it has to be noted that education has a bigger effect on the participation of women rather than that one of men. On the whole, in the Republic of Macedonia and in most of the countries in the region, women have better average results of education than men. However, it is more possible for women to choose generallyeducational programs, or social sciences as their primary area of education. (Gamberoni \& Posadas, 2012).

Although the existence of an important informal sector leads towards a possibility for overestimation of the factual unemployment, the very high unemployment is still an important issue, especially among the young and the less educated. Overall, the situation of the labour market has improved inconsiderably so that the unemployment continues to be very high, especially among the young and the less educated.

\section{Implementation of the educational policies as a challenge to the labour market in the Republic of Macedonia}

According to the National Strategy for Employment of the Republic of Macedonia for 2015, the reasons for the present unemployment should not be looked for only in the current situation, but also in the former years of transition, the process of privatization, the new market conditions, the informal economy, the building of poor infrastructure, the war conflict in 2001 and the low domestic and FDI. 
By taking into account the present reasons for high unemployment, it can be seen that they are more often placed in the insufficient labour demand which is largely a result of the poor economic growth in the past decade and the world economic crisis. The increased economic activity and the increased investments will contribute to the creation of new posts and the increase in employment. The labour market is further on characterized by high rate of unemployment, especially among the young and the lowqualified, by low rate of women's activation, as well as by long-term unemployment. Exactly the gender inequality and the insufficient proportion between the educational system and the needs of the labour market are some of the key challenges taking place at the labour market in the Republic of Macedonia. As a result, the proportion of the educational system with the labour demands, the training and voluntarism, the active programmes for employment as well as the promotion of the entrepreneurship are the basic priorities which are taken into account so that the principal aim of the rate of employment of $55 \%$ can be achieved till 2015.

In order to improve the structure and quality, the examination and development, and the use of human resources, in the last period a special attention was paid to the reforms in all levels of education being a main pre-condition for employment and provision of long-term economic development of the country. In that direction, it was initiated compulsory secondary education, it was increased the duration of primary education from 8 to 9 years, there have been created material conditions and it has been modernized the tuition for acquiring IT skills and raising the level of being in command of foreign languages by introducing a computer for every child, learning a foreign language from the earliest years, introducing entrepreneurship in the secondary schools and training in the higher education. The processes of reforms in education are being supported by the increased selection of resources from GDP for such purposes. From 3\% of GDP in 2006, the selection increased to $4.6 \%$ in 2010 , thus contributing to the raise of the level and quality of education and being a direct contribution to the improvement of the state of the labour market.

It has been increased the access to higher education being financed by the country which provides a regional dispersal and opening of new higher education institutions in a few smaller towns all over the country. Higher education is also being implemented by a lot of accredited private institutions of higher education in the Republic of Macedonia. This contributed to a considerable increase in the number of students enrolled in higher education, from 12.307 in the school year $2005 / 2006$ to 17.573 in $2010 / 2011$ i.e. an increase of $43 \%$.

\section{Conclusion}

Education achievements play a particularly important role in education. Therefore, there is an urgent need for improvement of the quality of education in the developing countries especially those being at a lower level as it is the case with the Republic of Macedonia. Starting from the fact that the primary education does not mean acquisition of skills on its own being quite awarded at the labour market (critical thinking, problem solving, behavioural skills as well as IT skills), there has been imposed the need for reforming the educational process so that it fulfills the needs of the labour market more adequately. On the other hand, the employment in the Republic of Macedonia is characterized by the very unfavourable gender structure. This structure has been unchanged for a long period of time, first of all, as a result of the unstable economic and social conditions in the country and the disproportion between the available and the necessary profiles of the labour market. The main factors which have an impact on the low women's activation at the labour market, are the tradition and cultural habits in the country, the low education and skills, the ethnic affiliation in combination with education, the availability and price of the services for taking care of children and the older members of a family, the presence of discrimination at the labour market, etc. From the perspective of the bearers of economic policy, this paper points out the fact that the gender gap in activation is related with education so that women with higher education are more active at the labour market than men with higher education.

Generally, in the past the public universities were those which were fulfilling the needs of the labour market for higher education staff. However, the processes of globalization, the political transformation and strengthening of private enterprise have largely disrupted this proportion. Nowadays, the labour market establishes new relations and relationships, transcending the narrow national frameworks and extending its scope at an international level. Because of the dynamics it is developing, the labour market has need of flexible and dynamic educational institutions. Therefore, the public institutions of higher education are being exposed to the challenge to alter their current structure, to bring about a new structural change and to develop an organizational structure which will be compatible with the general changes at the labour market.

\section{References}

Commander, S., \& Kollo, J. (2004). The Changing Demand for Skills: Evidence from the transition, IZA Discussion Paper, 1073.

Gamberoni, E., \& Posadas, J. (2012). Gender gaps in labor market outcomes: participation, unemployment, and wage gaps in FYR Macedonia. mimeo. World Bank. Washington DC.

Ministerstvo za obrazovanie i nauka na Republika Makedonija (2004). [Ministry of Education and Science of the Republic of Macedonia.]. Nacionalna programa za razvoj na obrazovanieto vo Republika Makedonija 2005-2015. [National Strategy for the development of education in the Republic of Macedonia 2005 - 2015].

MSSO. (2013). Macedonian State Statistical Office. (2013). Retrieved from http://www.stat.gov.mk/Default_en.aspx

OECD. (2013). Education at a Glance 2013: OECD Indicators. OECD Publishing. Retrieved from dx.doi.org/10.1787/eag-2013-en

Perlman-Robinson, J. (2011). A global compact on learning: Taking action on education in developing countries. Washington, DC: Center for Universal Education at Brookings.

World Bank \& ETF. (2008). Constraints to Labour Force Participation in FYR Macedonia: A qualitative approach, Eastern Europe and Central Asia Region. Human Development Department, Washington D.C.

World Bank. (2008). Active Labour Market Programs in FYR Macedonia, A Policy Note. World Bank, Human Development Sector Unit.

Yemtsov, R., Cnobloch, S. R., \& Mete, C. (2006). Returns on Schooling in Transition Economies, World Bank, Washington, DC. 